\title{
The Impact of Corporate Governance and Leadership on Entrepreneurship Development in Nigeria
}

\author{
${ }^{1}$ Atoyebi Kehinde .O., ${ }^{2}$ Adekunjo Felix .O., ${ }^{3}$ Kadiri kayode .I., \\ ${ }^{4}$ Ogundeji Musibau .O., ${ }^{5}$ Falana Adedamola .A. \\ 1,2,3,4,5 Dept. Of Economics. Lagos State University, Ojo.
}

\begin{abstract}
The study empirically examined the impact of leadership and corporate governance in Nigeria. The paper gather information through structured questionnaire and this was analysed through simple percentage, table for tabular analysis, and the spearman's rank correlation coefficient for the testing of formulated hypothesis. The results revealed that effective leadership and good corporate governance determines the success of organisation. In the analysis, we found out that corporate governance policy has really helped Nigerian entrepreneur to grow financially. Based on our findings, effective leadership and good corporate governance was a solution to global financial crises, organisation problems and the right policy that enhances increased productivity and economic growth in Nigeria.
\end{abstract}

Key words: Corporate Governance, leadership, entrepreneur, productivity.

\section{Introduction}

All enterprise and organizations, both profit and profile conduct their business through involvement and respect for those work in them, achieve superior results, Cadbury (1996) posited that leadership is the creation of vision about a defined future state, which seeks to enmesh all membership of an organizational setting, the effect which is relevant to the attainment of the organization goals.

Cooperate governance on its own is defined as an at, fact and manner of controlling, ruling and directing the public affairs of city, country e.t.c Enabunene (2005) defines it is the exercise of political power to move a nation's affair forward.

Considering the modern business environment, corporate govern an has biome a priority objective for emergent economics from Latin American to China and the world at large.

Recently, there has been considerable practices of modern corporations, particularly since the high profile collage of large US firms such as Enron Corporation and worldcom.

In Nigeria likewise, big firms which seems to be doing well such as Commercial Banks, Forum Limited, Universal Trust Bank Limited, Savannah Bank Limited and others, suddenly collapse due to array of problems ranging from ineffective leadership and corporate governance coupled with poor and instable economic environment.

There are other problems associated with this issues and they are:

Unethical behaviour on the side of the leaders, lack of cooperation among the operators of the organization, poor quality leadership styles in directing their affairs of the organization, territorial conflicts, i.e the extension of duties and responsibilities beyond one is jurisdiction which an lead to disagreement between the shareholders and the managers and a list more.

In the light of this background, the study will however adds to the existing literature by re-examine the impact of leadership and corporate governance on entrepreneurship development in Nigeria and also to take a cursory look at other factors affecting growth and entrepreneurship development in Nigeria. Also, analysing the relevance of ethnics in the business environment in Nigeria.

\subsection{PURPOSE OF THE STUDY}

The focus of this study is however on the impact of leadership and corporate governance on entrepreneurship development with reference to Zenith Bank Plc and Bank of Industry. The right of individual owners and shareholders, managers and their subordinates, has become a debatable issues globally, hence the need for effective leadership and corporate governance in the business environment especially Zenith Bank Plc and Bank of Industry to enhance efficiency. Other purpose of this research work is to:

Take a look at the other factors affecting the growth and development of entrepreneurship in Nigeria; Analyze the significance of ethics in the business environment (organization); Know the extent at which leadership and corporate governance has helped small and medium scale enterprises to combat organizational conflicts; Examine the impact of leadership and corporate governance on entrepreneurship development; Take a 
look at the relationship between leadership corporate governance and entrepreneurship development; Examine the contributions of entrepreneurship development to the growth and development of Nigerian economy.

\subsection{RESEARCH QUESTIONS}

To achieve direct result, this research work will attempt to ask the following questions.

Is there any relationship between leadership, corporate governance and entrepreneurship development?

Does the success of business organization depend largely on the quality of leadership and corporate governance?

Is selfish interest of the chief executive officers one of the factors affecting corporate governance in an organization?

Can an unethical behavior of the leaders hinder the smooth running of an organization?

Can ineffective leadership and poor corporate governance pose negative effect on entrepreneurship growth and development?

Does good leadership structure in business organizations enhances the achievement of superior results?

Can effective leadership and corporate governance create the rights climate for effective production and work satisfaction?

Do leadership corporate governance has positive impact entrepreneurship development?

Has entrepreneurship development contributed to the growth and development of the Nigerian economy?

\subsection{STATEMENT OF THE HYPOTHESES}

Osuala (2005) describes hypotheses as conjectural statement of the relationship between two or more variables. Therefore, the hypotheses formulated for this research work are shown below where (Ho) represents Null Hypothesis while (Hi) denotes Alterative Hypothesis.

Ho: Organizational success or otherwise does not depend largely on the quality of leadership and corporate governance.

Hi: Organizational success or otherwise depends largely on the quality of leadership and corporate governance.

Ho: There exist no significant relationship between leadership, corporate governance and entrepreneurship development.

$\mathrm{Hi}$ There exist a significant relationship between leadership, corporate governance and entrepreneurship development.

Ho: Ineffective leadership and poor corporate governance do not affect entrepreneurship development.

Hi: Ineffective leadership and poor corporate governance affect entrepreneurship development.

\subsection{SIGNIFICANCE OF THE STUDY (JUSTIFICATION)}

On this note, the study is justified based on the fact that leadership and corporate governance are needed in the banking industry for its development and so as affect positively entrepreneurship development. Since effective leadership and corporate governance structure determines the achievement, success and progress an organization can attain, this research work is very important to the banking industry, including Zenith Bank Plc, and entrepreneurs as it will help them to manage their enterprises to attain greater height. Also, this study will help the leaders to see the need to imbibe ethical behavior and inculcate it into their subordinates which will in no small measure help in combating unethical behavior in the organization and the society at large.

The rest of the study is organized as follows: section 2 reviews the existing literature and theoretical framework. Section 3 presents the data and the analysis of the results. The last section gives the summary, conclusion and recommendations

\section{Literature Review And Theoretical Framework}

The impacts of leadership and corporate governance on entrepreneurship development in Nigeria and the world at large can not be overemphasized. To have a better understanding about the above assertion, it is necessary to define and explain in details the following terms: leadership, corporate governance, and entrepreneurship development.

All enterprises and organizations, both profits and non-profits which conduct their business through involvement and respect for those who work in them, achieve superior results. Gannon (1977) states that without effective leadership, it is difficult for an organization to function effectively. Leaders or manager define the goals the organization pursues; they develop the planning and control systems that guide and monitor the organization's destiny; they construct an organizational structure appropriate for the tasks undertaken; and they motivate their subordinates to complete these tasks.

Cadbury (1996) assert that leadership is the creation of a vision about a defined future state, which seeks to enmesh all members of an organization in its net. He stated further that, a leader is one who designs and 
implement by way of instructing the subordinates, enthusiastically, motivating, encouraging and guiding them towards the achievement of the enterprises goals and objectives.

Colley, Doyle, Logan \& Stettinius (2004) posit that, leadership is a social influence in an organizational setting, the effect of which is relevant to or has an impact upon the achievement of organizational goals.

Lawal (1993) sees leadership as the process of influencing others to work willingly towards an organizations goal with confidence and keenness.

Effective leadership as earlier mentioned is a key factor in the life and success of an organization. Obviously, there are many factors involved in successful leadership. Many are difficult to measure, some are even hard to identify. In developing a profile of leadership, it is important to remember that simply being in managerial position does not make a person a leader. What assumptions does the manager make about the behavior of his/her subordinates? What is the relationship between assumptions and the types of power a manager may use? Here, the profile of leadership considers the idea that being a leader is not a single role but a group of important roles that managers play in the life of an organization.

Gannon (1977) in the work of Weber (1949), states that, in the past, a manager was automatically thought to be a leader. The manager did not need any formal training whatsoever in the area of leadership for it was assumed that subordinate automatically followed his orders. He states further that, a leader possesses power by virtue of his position, and power is the ability to give commands that must be accepted.

Gradually, the importance of leadership was recognized, because subordinates frequently disobeyed the commands of superior. As put forward by Mullins (2005) from the work of Barnard (1930) gives new definition of leadership as the ability of a superior to influence the behaviour of subordinates and persuade them to follow a particular course of action. Currently, managers view leadership no longer as a right of office but rather, as a skill that can and must be learned in order to motivate subordinates to be productive.

Corporate as a concept, is an adjective that is shared by all in a group. As such, it is a group and not just an individual. Entrepreneurial organization that is managed by just one individual cannot be properly described as being corporate, it must have a group of individuals heading the enterprise to be tagged corporate (Ogundele, 2007).

Governance is considered as that organ of small or big organization or even the larger society, which is charged with the responsibility for controlling resources, of all types, within the spheres of its influences, and also having power of rulership over the human and material resources, of the organization or community (Ogundele, Alaka and Balogun, 2005).

Omonzejie (2005) considers governance as an act, fact, and manner of controlling, ruling and directing the public affairs of a city, country, etc. He notes further that, governance as a process or the art of governing is a body vested with the power and authority to maintain security, peace and stability by making and enforcing conventional and fundamental law in a given state or society.

Enabunene (2005) postulates that governance connotes the manner in which government governs the territory and people it juristically control. That is, governance is the exercise of political power to move a nation's affairs which encompasses all the state's institutional and structural arrangements, decision-making process, and implementation capacity, and relationship between government official and the public. He notes that governance, therefore, consists of a nation's system of politics and its interconnection of public administration and law.

According to Keasey, Thompson \& Wright, (2005) corporate governance, is a term that scarcely existed before the 1990s, now universally in vogue wherever business and finance are discussed. The subject has spawned consultancies, academic degrees, encyclopedias, innumerable articles, conferences and speeches. Almost all the OECD Nations are currently revising their corporate governance or have recently done so while, the establishment of a viable corporate governance system has become a priority objective for emergent economics from Latin American to China. In the midst of so much interest, the underlying issues of the subject are always in danger of being swamped. Moreover, since good governance, like 'fair trade' and 'free competition' is an abstraction that commands near-universal respect but diverse interpretation; it has also become the destination board for a bandwagon carrying those who would, in fact, take the corporation in myriad directions.

They further argued that, not merely does the term corporate governance carry different interpretations, its analysis also involves diverse constrained by legal, regulatory, financial, economic, social, psychological and political mechanism which are themselves sometimes substitutes and sometimes complements. Academic researchers, predominantly coming from a single subject background will typically explore the operation of merely a subset of these and then in the context of the priorities of their own discipline. This inevitably means that research on the subject becomes Balkanized and less accessible.

Olayiwola (2010) states that corporate governance as a concept may be viewed at least from two perspectives - the narrow and the broad perspectives. The narrow view is concerned with the structure within a 
corporate entity or enterprise receives its basic orientation and direction. The narrow view perceives corporate governance in terms of issues relating to shareholder protection, management control and the popular principleagency problems of economic theory.

However, Oman (2001) observe that broader approach to corporate governance is the method by which suppliers of finance control managers in order to ensure that their capital cannot be expropriated and that they earn a return on their investment.

There is a consensus, however that the broader view of corporate governance should be adopted in the case of banking institutions because of the peculiar contractual form of banking which demands that corporate governance mechanisms for banks should encapsulate depositors as well as shareholders. Oyejide and Soyibo (2001) joined the consensus by depositor, by arguing that the special nature of banking requires not only a broader view of corporate governance, but also government intervention in order to restrain the behaviour of bank management. They further argued that, the unique nature of the banking firm, whether in the developed or developing world requires that a broad view of corporate governance, which encapsulates both shareholders and depositors, be adopted for banks. They posit that, in particular, the nature of the banking firm is such that regulation is necessary to protect depositors as well as the overall financial system.

According to Soyibo, Olayiwola, \& Alayande, (2002), in the Nigerian financial sector, poor corporate governance is identified as one of the major factor sin virtually all known instances of a financial institution's distress in the country. Thereafter the consolidation of the banking industry, however, necessitated a review of the existing code of the Nigerian banks. The 2006 Code of Corporate Governance for Banks in Nigeria Post Consolidation was developed to compliment other policies and enhance their effectiveness for the Nigerian banking industry. Compliance with the provisions of this code is mandatory. However the recent Global Financial Crisis, Asia Crisis and the bitter experience of banks distress and failure, suggest that Nigeria needs to take stock of its corporate governance.

Oyejide and Soyibo (2001) define corporate governance as the relationship of the enterprise to shareholders or in the wider sense as the relationship of the enterprise to society as a whole.

Ogundele, (2007) defined corporate governance as the system that relates to the patterns of arrangement within private organizations or companies, which vested individuals or groups with power and authority to control the affairs of an enterprise.

Dess and Lumpkin (2002) define corporate government as the relationship among various participants in determining the direction and performance of corporations. They noted that, the primary participants are shareholders, the managing headed by Chief Executive Office (CEO), and the board of directors.

Confederation of India Industry (CII) (1997) states that corporate governance deals with laws, procedures, practices, and implicit rules and determine a company's ability to take managerial decisions vis-à-vis its claimant- particularly, its shareholders, creditors, the state and employees.

They suggested that corporate governance be made more effective through shareholders activism, effective managerial rewards and incentive and committed and involved board of directors.

The concept of entrepreneur has a wide range of meanings. Entrepreneur is an individual who successfully thinks or conceives of a new business concern, organizes or initiate actions to start it, and manages it through its initial problems and struggles for survival. (Ogundele, 2000 and 2005).

Therefore, small and medium scale enterprises (entrepreneurs) in Nigeria need a good corporate governance to control and direct their day to day activities. Amit, Glosten and Muller (1993) define entrepreneur as individual who innovates, identifies and creates business opportunities, assembles and coordinates new combinations of resources, and extracting the most profit from his innovation in uncertain environment.

Entrepreneurship is an aspect of the concept entrepreneur. For this reason, Ogundele (2007) describes entrepreneurship as the processes of emergence, behaviour and performance of entrepreneurs. He notes that a focus on entrepreneur is a focus on the individual organization created while entrepreneurship is a focus on the processes involved in the initiation of a new organization, the behaviour of such organization and its performance in terms of profit made. Entrepreneurship therefore refers to the activities of individual entrepreneurs and the entrepreneurial groups at all the three phrases of emergence, behaviour and performance of entrepreneurs.

Hill and McGowan (1999) sees entrepreneurship as a process which involves the effort of an individual (or individuals) in identifying viable business opportunities in an environment, obtaining and managing the resources needed to exploit those opportunities.

Schumpeter (1934) an Australian economist found that the single function which constitute entrepreneurship concept is innovation such as new products, new production method, new market and new forms of organization. Wealth is created when such innovation 'results in new demand. However, in today's knowledge driven world, individual entrepreneurial skills have ceased to be the important determinants of business success but, organizational characteristics have assumed for greater importance on collaborative effort 
of networked individuals to identify and exploit business opportunities, to introduce new goods and services, ways of organizing markets, processes and new raw materials through organizing market efforts that previously not existed (Akanni, 2010).

Dollinger (2001) views entrepreneurship as a process which involves the creation of an innovative economic organization for the purpose of gain or growth under condition of risk and uncertainty. Entrepreneurship plays a major role in the economic development of countries that have developed entrepreneurial culture. For: instance, Price (2001) pointed out that, the secrete behind the successful economic growth and development of an enterprising nation like the United State of America is its ability to imbibe entrepreneurial culture. That is, ability to see entrepreneurs as a set of individual(s) that creates new business that brings about new job opportunities. He stressed further that; entrepreneurs create two out of three jobs and twice innovative as large companies in the USA.

In summary, the quality of leadership and corporate governance determines the success or otherwise of an enterprise or organization, especially small scale entrepreneur (Colley et al, 2004).

An organization may be likened to a vehicle, and every vehicle needs a good driver, if an organization is like a vehicle, then it has to be driven by a safety conscious pilot, a visionary and truly committed leader. A leader practices leadership through vision, character, mission and value, and is purposefully directed at predetermined collective goal. Leadership relies on due diligence, total quality management, efficiency, effectiveness and responsive followership (Anuku \& Achienu, 2011).

There are two major types of leadership styles-task-oriented and people-oriented types. The peopleoriented style is politically directed while task-oriented type is management and results in organizational effectiveness which is measured through performance and result. The function of leadership therefore, is to induce or persuade all subordinates or followers to contribute willingly to organizations goals in accordance with maximum capability.

According to Gannon (1977), without effective leadership, it is difficult for air organization to function effectively. Anuku \& Achienu (2001) states that effective leadership represents the quality of response to the environmental factors of time, culture, personalities, community, needs and products, and a harmonization of these environmental factors in an interplay to derive equilibrium in their operations. Adding that, such interplay of factors against circumstances and products enhances organizational effectiveness and performance. Here effectiveness consists of accountability, performance and achievement beyond the predermined objectives.

Anuku and Achienu (2001) describes corporate governance as the ability of the leader to effectively manage an organization in terms of accountability, transparency, excellent performance, achieving beyond the predermined objectives of the organization, quick response to environmental factors, identifying problems and proffered immediate solutions to the problems.

However, banking industry and small medium scale entrepreneurs, need effective leadership which is the ability of a superior to influence the behaviour of subordinates and persuade them to follow a particular course of action so as to achieve organizational goals likewise corporate governance which is all about the manner in which corporations are directed and controlled by an effective leadership are most required. (Mullins, 2005 and Wilson, 2006).

According to Wilson (2006), the clear lesson Enron, Parmalat, WorldCom, Barings Bank etc, taught the corporate world is that no company (or bank) is too big (financially or otherwise) to fall. That is, irrespective of the financial standard or capability of an organization be it bank or an entrepreneur, without an effective leadership and good corporate governance system will go bankruptcy. Therefore, effective leadership and good corporate governance are an essential ingredients to the success of every organization.

\section{Theories Or Approaches To Leadership}

Due to its complex and variable nature, there are many alternative ways of analysing leadership. It is helpful, therefore to have some framework in which different approaches to theories of leadership should be considered. These approaches or theories are mentioned and analyzed below.

The qualities or traits approach; The functional or group approach, including action-centred leadership; Leadership as a behavioural category; Styles of leadership; The situational approach and contingency models; Transitional or transformation leadership; and Inspirational model

\subsubsection{FUNCTIONAL (OR GROUP) APPROACH}

This approach to leadership focuses attention not on the personality of the leader, but on the functions of leadership. It views leadership in terms of how the leader's behaviour affects, and is affected by, the groups of followers. This approach concentrates on the nature of the group, the followers or subordinates. That is, the content of leadership. Attention is given to the successful training of leader and the means of improving the leader's performance that will lead to effective subordinates (work group) performance. 
The functional approach believes that the skills of leadership can be learnt; developed and perfected. In contrast to traits approach, Kotter (1990) states that successful companies do not wait for leaders to come along but, they seek out people with leadership potential and expose them to career experiences (training) designed to develop that potential. Indeed with careful selection, nurturing and encouragement, dozens of people can play important leadership roles in a business organization. Similarly, Whitehead (2002) pointed out that there has. been a dramatic change in how management thinkers regard leadership today. Leaders are not born, they say, but made. The good news is that everyone can do it, one does not need to be promoted to a management position or be the boss before becoming a leader, but can be a leader in whatever you do.

However, the contribution of Adair (1970) to functional approach is on "action centered leadership" which focuses on what leaders actually do. The effectiveness of the leader is dependent upon meeting three areas of need, within the group work: the need to achieve common task, the need for team maintenance, and the individual need of groups members.

These needs are symbolized by three overlapping circle.

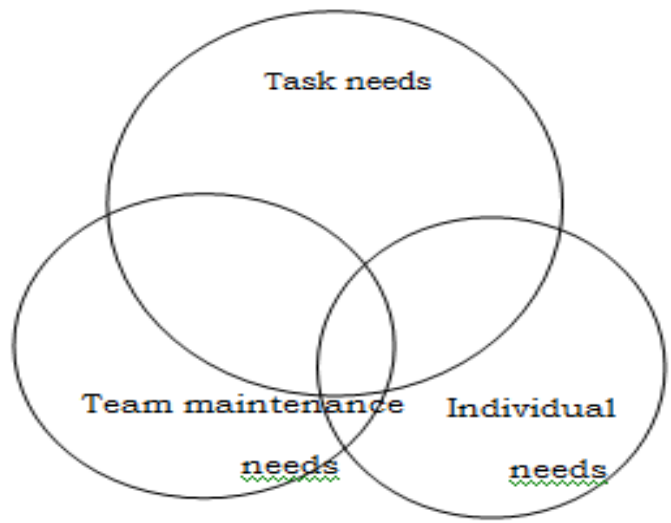

Fig 2.1 Interaction of needs within the group

\subsubsection{LEADERSHIP AS A BEHAVIOURAL CATEGORY}

This approach draws attention to the kinds of behaviour of people in leadership situations. One of the most extensive research studies on behavioural categories of leadership was the Ohio state leadership studies undertaken by the Bureau of Business Research at Ohio state university. The focus was on the effects of leadership styles on group performance, that is, it is to determine the relationship between effective leader behaviour and subordinates' satisfaction and performance. The result shows that effective leaders exhibit different behaviour in different situations. The two major dimensions of behaviour are:

Consideration reflects the extent to which the leader establishes trust, Mutual respect and rapour with the group and shows concern, warmth, support and consideration for subordinates. This dimension is associated with two-way communication, participation and the human relations approach to leadership.

Initiating structure reflects the extent to which the leader defines and structures group interactions towards attainment of formal goals and organizes group activities. This dimension is associated with efforts to achieve organizational goals.

Further research conducted shows that while both are necessary for effective leadership, it is more important for a leader to know how to use strike a balance between the two. That is identifying the appropriate combination for particular situation rather than exhibiting a high degree of both at all times.

Other leadership theories, approaches or studies under behavioural category are Michigan studies and Blake and Mouton Management grid.

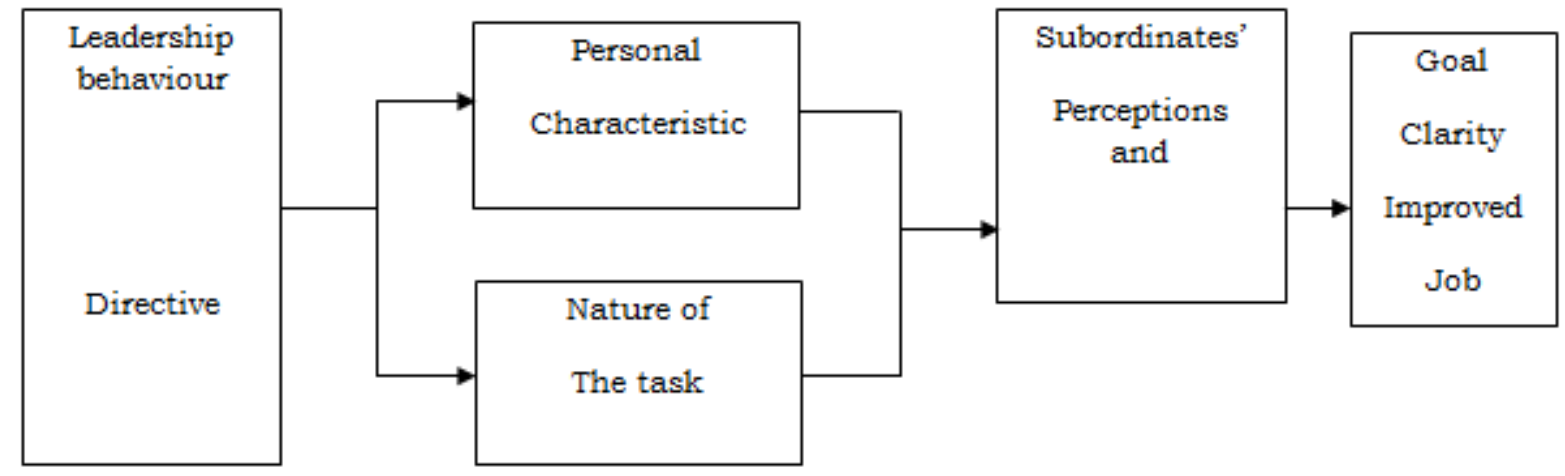

Fig 2.4 Path-goal theory of leadership 
(Source: Mullins, L.J., Organizational Behaviour, Pearson Education (2005) P.30)

Leadership behaviour is determined by two main situational factors such as the personal characteristics of subordinates; and the nature of the task as shown in fig 2.5 above, are demonstrated, below

The personal characteristics of subordinates determine how they will react to the manager's behaviour and the extent to which they see such behaviour as an immediate or potential source of need satisfaction.

The nature of the task relates to the extents that it is routine and structured, or non-routine and unstructured.

For instance, when a task is highly structured, the goals readily apparent and subordinates are confident, then attempts to further explain the job or to give directions are likely to be viewed as unacceptable behaviour. On the other hand, when the task is highly instructured, the nature of the goals is not clear and the subordinates lack experience, then a more directive style of leadership behaviour is likely to be welcomed by subordinates. Therefore, effective leadership behaviour is based on both the willingness of manager to help subordinates and the needs of subordinates for help. Leadership behaviour will be motivation to the extent that it provides necessary direction, guidance, and support; helps clarify path-goals relationships and removes any obstacles which hinders attainment of goals (Mullins, 2005).

\subsection{GLOBAL CONCERN FOR ETHICAL CORPORATE GOVERNANCE}

The issue of ethic in corporate governance has received global attention in recent times. Kamzi (2003) notes that globally, there has been concern the biased and sometimes outright unethical practices adopted by held companies. In United Kingdom, the Cadbury committee went into various aspect of financial matters related to governance of companies by its boards. The reports prepared by the committee have generated a lot of interest worldwide (Kamzi, 2003).

Dess and Lumpkin (2002) notes that if corporate America succeeds in re-making governance, one of the greatest ironies will be that we have Enron to thank for it. This was due to the fact that unquestioning faith which Enron's board placed on the company's management was revealed to be a colossal blunder. Faith in other once-revered executives also began to falter. As a result, Enron, and corporate disasters that followed forced many companies to get serious about governance.

In Nigeria, Cadbury Nigeria PLC, is the Enron of our environment. Madueke (2007) reports that Cadbury had been overstating its profits for so many years. A close examination of its books revealed that it indulged in that unwholesome practice for quite sometime, and as a result, overstated its profits to the tune of $\$ 15$ billion. Cadbury had made, profit in the past but in this particular case was a lie and that was what made it all wrong. The company directors lied to the owners of the company, the share holders, those who regulate corporation; Nigerian Stock Exchange and the Securities and Exchange Commission; the Federal Government and relevant agencies; the suppliers, employees and the general pubic that they made profit when they did not. The unethical behaviour of the board of Cadbury Nigeria Plc, will continue to be one of the most abiding corporate sleaze of such magnitude. (Madueke, 2007). He notes further that it was not in isolated case, that falsification of annual reports has been an insider practice in corporate Nigeria for ages.

\subsubsection{GLOBAL ISSUES IN CORPORATE GOVERNANCE}

According to Fitzroy and Herbert (2006) each country has its own distinct type of corporate governance reflecting its history as well as its legal, regulatory, and tax regimes. But all over the world there are concerns with inadequate governance arrangements. Switzerland has had problems with Swissair and UBS, Swedon with ABB, Korea with Daewoo, Germany with Kirch, France with Vivendi, Italy with Parmalat, and, of course, the United States with Enron and World Com. As a result, countries are re-examining the way companies are managed. Germany has had a committee *Under the chairmanship of Gerhard Cromme, the head of Thyssenkrupp; France Verniot Report; and the United Kingdom Hampel Committee in 1998; the U.S congress passed the Sarbanes-Oxley Act, attempting to improve the governance of American Corporations.

Flaws in the way in which companies are managed have focused attention on corporate governance and the role of boards of directors. At the same time, globalization-with the adoption free-market system and the removal of trade barriers, together with technological advances in communication and transportation has led to higher levels of competitive intensity in both product and capital markets. As a consequence investors, both institutional and individual, have recognized that the quality of corporate governance affects the firm's competitive performance and hence its ability to attract investment capital. Fitzroy and Herbert (2006) states that there is a growing recognition in all countries that the expectations of shareholders have to be met when the firm relies on the financial markets for debt and equity. At the same time, boards of directors need to give consideration to the needs of other stakeholders such as customers, employees, suppliers, creditor and the community. 


\subsection{LEGAL AND REGULATORY FRAMEWORK FOR CORPORATE GOVERNANCE IN NIGERIA}

In Nigeria, as in most developed countries, observance of the principles of corporate governance has been secured through a combination of voluntary and mandatory mechanism. In 2003, the Atedo Peterside Committee (APC) set up by Securities and Exchange Commission (SEC), develop a Code of Best Practice for Public Companies in Nigeria. The code is voluntary and is designed to entrench good business practices and standards for boards and directors, CEOs, auditors, etc., of listed companies, including banks.

Mandatory corporate governance provisions relating to banks are contained Companies and Allied Mattes Act (LAMA) 1990, the Banks and other financial Institution Act (BOFIA) 1991, the investments and Securities Act 1999, the Securities and Exchange Commission Act (SECA) 1988 and its accompanying Rules and Regulation), etc. and only recently the CBN issue' a Code of Conduct for Directors or Licensed Banks and Financial Institutions issued by the Central Bank of Nigeria and a Code of Corporate Governance for Banks in Nigeria Post consolidation 2006. Compliance with the provisions of these codes is compulsory.

It is a credit to Nigeria that these extant laws and codes (which place responsibility for regulating corporate governance on the CAC, SEC and CBN reflect some of the OECD and Basel principle. The key highlights of the SEC and CBN codes include:

Separating the roles of the CEO and the board chairman; Prescription of non-executive and executive directors on the board; Improving the quality and performance of board membership; Introducing merit as criteria to hold top management positions; Introducing transparency, due process and disclosure requirements; Transparency on financial and non-financial reporting;

Protection of Shareholder rights and privileges; and Defining the composition, role and duties of the audit committee etc.

\subsection{PRACTICE OF CORPORATE GOVERNANCE IN NIGERIA}

Following the leadership of Ricardo (2000) and as documented by Oyejide and Soyinbo (2001), reviewed the different provisions of legislation governance corporate governance in the Nigerian banking industry from three perspectives: disclosures and transparency; minority and shareholders rights; and oversight management.

\subsubsection{Disclosure and Transparency Issues}

In the section, we review the various laws governing the practice of corporate governance in the Nigerian banking industry are reviewed. These are:

Financial Performance: The basic company law is the Companies and Allied Matters Decree (CAMD) of 1990. It provides that the directors of every company shall prepare financial year. The financial statements must include, among others, the balance sheet and profit and loss accounts; the source and application of funds, giving information about the generation and utilization of funds; the value added statement reporting the wealth created by the company during the year; and the live year summary which provides comparative inter-temporal performance information. The financial statement must be laid before the share holders at the Annual General Meeting (AGM). These statements must reach the shareholder, who must decide whether to approve or reject the financial statements, at least 21 days before the AGM. The CAMD also provides for the annual preparation of the Directors' Report which should shareholders a fair view of the developments of the business of the company; its principal activities during the year and any significant change in those activities.

Auditing Matters/ Required Accounting and Auditing Standards: The Company Law specifies that all companies must appoint at its AGM, auditor or auditors to audit the financial statements of the company and hold office until the next AGM. In case where no auditors are appointed or statement of the company and hold office until the next AGM. In cases where no auditors are appointed or re-appointed, the law empowers the directors to appoint a person to fill the vacancy. It also provides for the procedure for reappointing any retiring auditor without a resolution being passed at the AGM. To ensure the independence of the auditor, CAMD prohibits any officer or servant of the company from being an auditor, neither can who is a partner or is in the employment of any officer of the company, nor is any person or firm that offers consultancy services to it. Additionally, for a bank, no person who has any interest in the bank other than as a depositor or who is indebted to the bank; no firm in which a director of the bank has interest as director or as a partner shall be an auditor. The BOFID also requires that any auditor appointed by any bank must be approved by the Central Bank of Nigeria (CBN). The auditor is expected to form an opinion as to whether the company kept proper accounting records and proper returns relevant for the audit have been received the branches not visited. The auditor will also tell whether the company's balance sheet and profit and loss account are in agreement with the accounting records and returns. 
Requirements for Equity Ownership Disclosure: The law requires that each company must keep a register of members/ shareholders where the shares held bar each holder is recorded as well as the amount paid or agreed to be paid. Whenever shares are sold they must also be recorded in the register. For a Plc, in addition to the register, the law also requires that unless the register is in s-ach a form that it constitutes in itself an index, the company shall keep an index of the names of the members of the company. In the case when any alteration is made in the register of members, the company must within 14 make any necessary alteration in the index. The index is expected to have sufficient information to enable the account of any member to be easily located. The register or index shall be open for inspection during office hours expect when the register of members is closed, subject to such restriction that the company in general meeting may impose and such that not less than 2 hours in each day shall be allowed for inspection.

Disclosure on Sundry Issues and Items: An important issue in corporate governance relates to the requirements of the company law in relation to disclosure on identity, compensation, background of directors and senior managers and of the relationship between directors and senior managers, as well as disclosure of related party transactions. As stated earlier any change in ownership interest and values must also be updated and be made known to all shareholders who have a right to ask for a copy of the register, or any part thereof, albeit, at a fee. The company law requires that the identity of directors, the size of their shareholding and their remuneration be in the public domain and thus be known and available to all shareholders. Accordingly, the law requires that a register of all members of the company including its index, where appropriate, be maintained in its registered office. In addition, parts V and VI of Schedule 3 of CAMD specify that the compensation of directors and number of employees remunerated at higher rates be made public. Besides, as mentioned earlier, disclosures on transactions and agreements on loans, quasi loans and other dealings in favour of directors and "connected persons" mandatory under the law.

\subsubsection{Oversight Management. In carrying out her duties, the management oversees the following.}

Mechanism and Structures for Prudent Management of Shareholders' Asset

There are many rules and regulations for ensuring that management of companies act in the interest of investors and of the firms. Among these are the shareholders' meeting which have supervisory functions over the companies; the requirements that financial accounts of companies be certified by external auditors; the different returns the companies are expected to send to regulatory agencies like the Corporate Affairs Commission (CAC) which registers all reported companies; the SEC which registers all shares of quoted Plcs; the Bank of Nigeria $(\mathrm{CBN})$ and the Nigeria Deposit Insurance Corporation (NDIC) which have regulatory and supervisory mandates for licensed banks and other financial institutions like finance houses and community banks, the National Insurance Commission of Nigeria (NAICOM), which has regulatory mandate over insurance companies. Shareholders can use their meetings to express and exercise their collective will as a corporate body. It is these meetings that all shareholders get to express their opinions about the way the company is run and make suggestions about how the company operations can be improved. In these meetings shareholders have the right to speak and vote on resolutions concerning the affairs of the company. In Nigeria, the CAMB provides for two main types of meetings: Statutory and General Meetings.

The use of external auditors to examine the books of companies is a way of exercising oversight management.

Section 357 of CAMD provides that all companies must appoint a qualified person as external auditors who must make a report to the all members of the company on all accounts they examined, and on every balance sheet and profit and loss account and on all group financial statement copies, which are to be laid before the company at AGM during the tenure of the auditor. Besides, Section 29 of BOFID prescribes that auditors of licensed banks must be approved by CBN. This is another way of exercising oversight management of banks. In particular, Subsection 5 of the same section provides that every auditor shall have a right of access, at all times, to the books, accounts and vouchers of the bank and shall be entitled to require from directors, managers, officers of the bank such information and explanation that he thinks for the performance of his duty. Additionally, Subsection 6 requires that two of the auditor's report and that of the directors together with the auditor's analysis of bad and doubtful advances in a prescribed form be forwarded to the CBN.

\section{Mechanism for Effective Oversight of the Audit Function}

The Audit Committee for Public Limited Companies, elected annually at the AGM, provides some measure of oversight for the audit function. However, its effectiveness is an empirical question. The membership is equally distributed between the Board of Directors and other shareholders subject to a maximum of six. Among the functions of the Committee which are germane to oversight of the audit functions are:

review of the scope and planning of the audit requirements; review of the findings on management matters in conjunction with the external auditor and the internal responses thereon; keeping under review the 
effectiveness of the company's system of accounting and internal control; making recommendations to the Board regarding the removal and remuneration of external auditors; and authorizing the internal auditor to carry out investigation into any activities of the company which may be of interest or concern to it.

Liabilities and Sanctions for Directors who Fail to Perform

The AGM with its power to appoint and remove directors as well as approve their remuneration is expected to act as check on the performance of directors. Accordingly directors will endeavour to bring to the AGM results that will win the approval and commendation of shareholders. Besides, certain sections of the company law prescribe penalties for erring directors and officers of the company. For example, Section 348 of CAMD prescribes the penalty for each director of any company that lays a faulty financial statement before any meeting of shareholders. If the company is in liquidation, for example, Section prescribes the offences that can be committed by officers of the company antecedent to or in the course of winding up. Section 503 prescribes penalty for falsification of company books; Section 504, for frauds while See prescribes the liability for not keeping proper accounts.

Section 507 prescribes the power of law courts to assess damages delinquent directors while the prosecution of delinquent officers and members of the company is provided for in*Section 508 of CAMD.

\subsection{THEORIES OF ENTREPRENEURSHIP}

Several theories have been developed over the years in attempts to explore and explain the entrepreneurship phenomenon. These include among others, economic, socio-cultural, managerial, educational, developmental, experiential, innovation, network, structural and multi-dimensional theories. Each of these theories had been used in the study of the processes of entrepreneurship.

Economic Theory: The economists see the entrepreneurship as the man who perceives business opportunities and takes advantage of scare resources to use them. Relevant, therefore, are the structure of economic incentives that are available in the market. Writers on this approach include (Schumpeter, 1934; and Drucker, 1985). The patterns of economic incentives have acted as stimuli for the emergence of entrepreneurs. They have also influenced the positive responses in terms of behavior and their performance (Kilby, 1965; and Singh, 1985).

Socio-Cultural Theory: The socio-cultural approach sees entrepreneurship as a social role and entrepreneurial development as a function of the form of society and the characteristics of culture. The socio-cultural environment have aided entrepreneurship by providing funds, business ideas, valuable information and other forms of social supports, thus directly influencing the processes of emergences, behaviour and performance of entrepreneur.

Political Theory: The influence of the political factor on eh emergence, behaviour and performance of entrepreneurs had been reported by several writers. Schatz (1962 and 1964) discussed tow forms of asstiance that were provided for indigenous entrepreneurs by government in Nigeria. These were (1) the financial support through the Federal Loan Board and (2) the establishment of the Yaba Industrial Estate for use by indigenous entrepreneurs. Ogundele (2000) discussed the provision of training and financial asstiance by government to indigenous entrepreneur through National Directorate of Employment (NDE). Government by way of legislations and provision of infrastructure and other support system have aided the entrepreneurial process.

Managerial Theory: This perceptive focuses on the perception of market opportunities. It in addition emphases the operational skills requires to run a successful enterprises. Kilby (1971) listed thirteen managerial functions, which the entrepreneurs might have to perform for the successful operation of their strategic managing practices as the function of entrepreneurs. Therefore managerial skills will have direct positive effect on the entrepreneurship processes of emergence, behaviour and performance. The environment that provides opportunities for relevant skills acquisition will tend to promote entrepreneurship.

Development Theory: This approach views entrepreneurship as an extension of the process of occupational choice in the individuals. This in turn is part of the individuals' total striving for an adequate life adjustment, and as such supportive training and development must be given to such individuals (1990). The developmental approach focuses on the development of entrepreneurial skills. At the macro level, it involves training in opportunity awareness, relating to relevant publics technology, market and dealing with government agencies. At the micro level, areas of focus include attitudes, motivation, education and work experience. This approach envisaged the positive effects of training and development on several determinants that effect entrepreneurs. The National Directorate of employment (NDE) in Nigeria adopted this approach and also provided fund for trained entrepreneurs. Thus, it provides both developmental and financial opportunities. 
Educational Theory: It is concerned with general level of education in the society. Its proponents contended that education tend to broaden peoples' outlook. It equips people with needed skills to look at the world around them in a more organized and coordinated fashion. This will make them to perform better in entrepreneurial role Akeredolu-Ale (1975) found that more entrepreneurs had lower levels of formal education than the civil servants. He could not establish any direct association between the level of formal education of entrepreneurs and the degree of success achieved. He reported that the general conclusion that entrepreneurs are less well educated than the general population was not supported by their study. Singh (1986) found that earlier notion that hose lacking educational qualification were usually the ones who went in for business was not borne out on his study.

\subsection{ENTREPRENEURSHIP DEVELOPMENT IN NIGERIA}

Development is defined as gradual advancement through progressive stage of growth from within (Hornby, 1974), Baech (1975) considered development as a systematic process of training and growth through which the individuals gain and apply skill, knowledge, insight and attitude to manage work organisation effectively. Development is thus seen as process which involves growth. These features of development imply "change". One has to bear this in mind in any considered of development of entrepreneur. The developmental approach to entrepreneurship, considers nurturing the actual or potential entrepreneurs to become effective in running their own organizations. This has to be done at various stages and in various institutions by three factors. First, is his own attitude towards his occupation. The second role is the expectations held by the sanctioning groups. The third is the operational requirements of the job. He noted that society's values are the most important determinants of the first two factors. Ekpo-Ufot (1988) gave an account of an entrepreneurship development programme that was carried out at the University of Lagos. He therefore, produced a list of seven determinants that affect entrepreneurship responses. These determinants are - society's value and needs, family, schools, work organisation, urbanization and industrial estates, availability of financial resources and structured to accelerate entrepreneurship development. He added that these determinants can accelerate entrepreneurship development only through the development of planning skills in the entrepreneurs with the provision of the feasibility study of their projects. Okaka (1990) observed that entrepreneurial success depends on possession of certain qualities in addition to the skills and knowledge concerning the technical aspect of owning a business. Such skills could be acquired through organized training and development. Rao, Wright, and Mukherjee (1990) noted that the focus of the development is entrepreneurial skills. Such skills include:

development of entrepreneurial spirit, characteristics and personality; development of technical technology and professional competence needed for productive work employment; development of enterprise building and small business development capabilities to initiate and start one's own business or self-employment and development of managerial capability to run the business and other self-employment activity successfully.

\section{Conclusion}

Different types of leaders are needed at different stages of the development of a company as supported by Rodrigues. Organizations functioning within a dynamic environment experience three stages of change; a problem-solving stage, an implementation-of-solution stage, and a stable stage. At each of these three organizational stages a leader with different trait, abilities, and behaviour is most effective. Organizations which exist in a dynamic environment therefore generally require the effort of dynamic leaders. Since they is no type of leadership style or approach that is more appropriate than the other a one time or the other, therefore, leaders are expected to make use of the leadership style based situation surrounding them. On the other hand corporate governance issues are receiving greater attention in both developed and developing countries as a result of the increasing recognition that a firm's corporate governance affects both its economic performance and its ability to access long-term; low-cost investment capital. Numerous high-profile cases of corporate governance failure have focused the minds of governments, companies and the general public on the threat posed to the integrity of financial markets, although it is not clear that any system will or should prevent business failures, or that it is possible to provide a guarantee against fraud. Therefore, what constitute good and bad corporate governance remain the global issues.

However, entrepreneurship, as a process which involves the effort of an individuals in identifying viable business opportunities in an environment and obtaining and managing the resources needed to exploit those opportunities i.e small and medium scale industry (SMI) remain one of the sectors that enhances economic growth and development. Therefore, every nation, be it developed or developing must ensure that effective leadership and good corporate governance.

\section{Data Presentation And Analysis Of Result}

This section deals with the presentation and analysis of the data collected for this research work. The data were presented and analyzed with regards to response to the research questions. All the data were presented 
in tables which show the response in percentage. The data collected are presented and analyzed below so as to have a better understanding of the impacts of leadership and corporate governance on the banking industry entrepreneurship development.

\subsection{RESPONDENTS' CHARACTERISTICS AND CLASSIFICATION}

The respondents' characteristics and classification as presented in section 'A' of this research work which stands as the personal data of the respondents are stated below:

Table 1: Sex distribution of respondents

\begin{tabular}{|l|l|l|}
\hline Respondent & No of respondents & \% of respondents \\
\hline Male & 52 & 52 \\
\hline Female & 48 & 48 \\
\hline Total & 100 & 100 \\
\hline
\end{tabular}

Source: Author's computation 2012

Table 1 above indicates that 52 or $52 \%$ of the total number of the respondents sampled were male which represents the majority, while 48 or $48 \%$ were female. This implies that the number of male in these organizations were more than their female counterpart.

Table 2: Age distribution of the respondents

\begin{tabular}{|l|l|l|}
\hline Respondent & No of respondents & \% of respondents \\
\hline $21-30 \mathrm{yrs}$ & 38 & 38 \\
\hline $31-40 \mathrm{yrs}$ & 31 & 31 \\
\hline $41-50 \mathrm{yrs}$ & 23 & 23 \\
\hline $51-60 \mathrm{yrs}$ & 6 & 6 \\
\hline $61 \mathrm{yrs} \&$ above & 2 & 2 \\
\hline Total & 100 & 100 \\
\hline
\end{tabular}

Source: Author's computation 2012

Table 2 above shows that out of the total population of the respondents, majority with a total number of 38 or $38 \%$ were with in the age bracket of 21-30years, 31 or $31 \%$ were within the age bracket of 31-40 years, 23 or $23 \%$ were within the age bracket of $41-50$ years, 6 or $6 \%$ were within the age bracket of 50-60years, while 2 or $2 \%$ were within the age bracket of 61 years and above. From the above analysis, it could be inferred that majority of the respondents were still young, agile, productive and mobile to run the affairs of these organizations effectively.

Table 3: Marital status of the respondents

\begin{tabular}{|l|l|l|}
\hline Respondent & No of respondents & \% of respondents \\
\hline Single & 42 & 42 \\
\hline Married & 56 & 56 \\
\hline Divorced & 02 & 02 \\
\hline Widow (er) & - & - \\
\hline Total & 100 & 100 \\
\hline
\end{tabular}

Source: Author's computation 2012

Table 3 above shows that a total of 42 or $42 \%$ of the respondents were single, 56 or $56 \%$ were married, 2 or $2 \%$ were divorced, while none was widow(er). This is to say that, majority of the respondents are married, which means that they are responsible people.

Table 4: Educational Qualification of the respondents

\begin{tabular}{|l|l|l|}
\hline Respondent & No of respondents & \% of respondents \\
\hline ND/NCE & 23 & 23 \\
\hline HND/B.Sc & 41 & 41 \\
\hline MBA/M.Sc & 30 & 30 \\
\hline Others & 6 & 6 \\
\hline Total & 100 & 100 \\
\hline
\end{tabular}

Source: Author's computation 2012

Table 4 above which portrayed educational qualification of the sampled population reveals that, a total of 23 or $23 \%$ of the respondents were ND/NCE holder, 41 or $41 \%$ were HND/B.Sc Certificate holder, 30 or $30 \%$ were 
MBA/M.Sc certificate holder while 6 or $6 \%$ holds other certificates. This indicates that majority of the respondents are well educated.

Table 5: Work experience of the respondents

\begin{tabular}{|l|l|l|}
\hline Respondent & No of respondents & \% of respondents \\
\hline $0-5 \mathrm{yrs}$ & 34 & 34 \\
\hline $6-10 \mathrm{yrs}$ & 43 & 43 \\
\hline $11-15 \mathrm{yrs}$ & 14 & 14 \\
\hline $16 \mathrm{yrs} \&$ above & 9 & 9 \\
\hline Total & 100 & 100 \\
\hline
\end{tabular}

Source: Author's computation 2012

As regards the work experience of the respondents from table 5 above, it was shown that, 34 or $34 \%$ of the respondents has between $0-5 y r s$ experience, 43 or $43 \%$ has between 6-10years experience, 14 or $14 \%$ has between 11-15 years experience while 9 or $9 \%$ has between 16 years and above experience. The above illustration shows that majority of the respondents had spent between 6-10 years in these organizations.

\subsection{PRESENTATION AND ANALYSIS OF DATA ACCORDING TO RESEARCH QUESTIONS}

Respondents' response to the research questions in section B of this research work are presented and analyzed thus:

Table 6: Good leadership and corporate governance are essential ingredients for organizational success.

\begin{tabular}{|l|l|l|}
\hline Respondent & No of respondents & \% of respondents \\
\hline Strongly Agreed & 50 & 50 \\
\hline Agreed & 43 & 43 \\
\hline Undecided & 1 & 1 \\
\hline Strongly Disagreed & 2 & 2 \\
\hline Disagreed & 4 & 4 \\
\hline Total & 100 & 100 \\
\hline
\end{tabular}

Source: Author's computation 2012

In response to the question in table 6 above, majority of the respondents with a total number of 46 or $46 \%$ strongly agreed with the question, 40 or $40 \%$ agreed, 3 or $3 \%$ undecided 4 or $4 \%$ strongly disagreed while 7 or $7 \%$ disagreed. This revealed that for any organization to record success, good leadership and corporate governance are required.

Table 7:There exist a significant relationship between leadership, corporate governance and entrepreneurship development.

\begin{tabular}{|l|l|l|}
\hline Respondent & No of respondents & \% of respondents \\
\hline Strongly Agreed & 38 & 38 \\
\hline Agreed & 49 & 49 \\
\hline Undecided & 4 & 4 \\
\hline Strongly Disagreed & 5 & 5 \\
\hline Disagreed & 4 & 4 \\
\hline Total & 100 & 100 \\
\hline
\end{tabular}

Source: Author's computation 2012

With regards to the question in table 7 , whether there exists a significance relationship between corporate governance and organizational development or not, 38 or $38 \%$ of the respondents strongly agreed, majority with a total of 49 or $49 \%$ agreed, 4 or $4 \%$ undecided, 5 or $5 \%$ strongly disagreed, while 4 or $4 \%$ disagreed. As majority of the respondents agreed, it shows that, there exists a strongly relationship between corporate governance and organizational development.

Table 8: An organization cannot function effectively without effective leadership.

\begin{tabular}{|l|l|l|}
\hline Respondent & No of respondents & \% of respondents \\
\hline Strongly Agreed & 38 & 38 \\
\hline Agreed & 44 & 44 \\
\hline Undecided & 2 & 2 \\
\hline Strongly Disagreed & 5 & 5 \\
\hline Disagreed & 11 & 11 \\
\hline Total & 100 & 100 \\
\hline
\end{tabular}


Source: Author's computation 2012

From table 8 above, it was revealed that 38 or $38 \%$ of the total number of the respondents sampled strongly agreed, 44 or $44 \%$ agreed, 2 or $2 \%$ undecided, 5 or $5 \%$ strongly disagreed, while 11 or $11 \%$ disagreed. This implies that, if not completely impossible but it would be very difficult an organization to function effectively without on effectively leadership.

Table 9: Organizational success or otherwise depend largely on the type or quality of leadership style used by the leaders.

\begin{tabular}{|l|l|l|}
\hline Respondent & No of respondents & \% of respondents \\
\hline Strongly Agreed & 36 & 36 \\
\hline Agreed & 48 & 48 \\
\hline Undecided & 5 & 5 \\
\hline Strongly Disagreed & 6 & 6 \\
\hline Disagreed & 5 & 5 \\
\hline Total & 100 & 100 \\
\hline
\end{tabular}

Source: Author's computation 2012

In view of table 9 above, the tabular analysis shows that 39 or $39 \%$ of the respondents 53 or $53 \%$ strongly agreed, 48 or $48 \%$ agreed, 2 or $2 \%$ undecided, 5 or $5 \%$ strongly disagreed while 4 or $4 \%$ disagreed completely. This means that organizational success depends largely on the types or quality of leadership style put in place by the leaders of such organization.

Table 10: Effective leadership and good corporate governance create the right climate for effective production and job satisfaction.

\begin{tabular}{|l|l|l|}
\hline Respondent & No of respondents & \% of respondents \\
\hline Strongly Agreed & 40 & 40 \\
\hline Agreed & 43 & 43 \\
\hline Undecided & 3 & 3 \\
\hline Strongly Disagreed & 5 & 5 \\
\hline Disagreed & 9 & 9 \\
\hline Total & 100 & 100 \\
\hline
\end{tabular}

Source: Author's computation 2012

According to the respondents in table 10 above, it was revealed that 40 or $40 \%$ of the total population sampled strongly agreed, 43 or $43 \%$ which represents the majority agreed, 3 or $3 \%$ undecided, 5 or $5 \%$ strongly disagreed while 9 or $9 \%$ disagreed. The tabular analysis shows that, corporate governance as a policy has helped Nigerian Bank to grow financially since the Bank consolidation.

Table 11:Corporate governance as a policy, strategy, instrument or system helps every organization to achieve her goals.

\begin{tabular}{|l|l|l|}
\hline Respondent & No of respondents & \% of respondents \\
\hline Strongly Agreed & 43 & 43 \\
\hline Agreed & 40 & 40 \\
\hline Undecided & 3 & 3 \\
\hline Strongly Disagreed & 9 & 9 \\
\hline Disagreed & 5 & 5 \\
\hline Total & 100 & 100 \\
\hline
\end{tabular}

Source: Author's computation 2012

Table 11 above revealed that, a total of 43 or $43 \%$ of the respondents which stands as the major strongly agreed that, corporate governance helps every organization to achieve her goals, 40 or $40 \%$ agreed, 3 undecided, 9 or $9 \%$ strongly disagreed while 5 or $5 \%$ disagreed.

Table 12: Global financial crisis is one of the major reasons for the general acceptance of corporate governance policy.

\begin{tabular}{|l|l|l|}
\hline Respondent & No of respondents & \% of respondents \\
\hline Strongly Agreed & 49 & 49 \\
\hline Agreed & 40 & 40 \\
\hline Undecided & 0 & 0 \\
\hline Strongly Disagreed & 3 & 3 \\
\hline Disagreed & 8 & 8 \\
\hline Total & 100 & 100 \\
\hline
\end{tabular}


Source: Author's computation 2012

Table 12 above, shows that, majority of the respondent were of the opinion that, global financial crises is one of the reasons for the general acceptance of corporate governance with a total number of 49 or $49 \%, 40$ agreed, none was undecided, 3 or $3 \%$ strongly disagreed, while 8 or $8 \%$ disagreed.

Table 13: Effective leadership and good corporate governance has been a solution tools for global financial crises.

\begin{tabular}{|l|l|l|}
\hline Respondents & No of respondent & \% of Percentage \\
\hline Strongly Agreed & 54 & 54 \\
\hline Agreed & 40 & 40 \\
\hline Undecided & 2 & 2 \\
\hline Strongly Disagreed & 0 & 0 \\
\hline Disagreed & 4 & 4 \\
\hline Total & 100 & 100 \\
\hline
\end{tabular}

Source: Author's computation 2012

Table 13 above shows that, out of the total population sampled, 54 or $54 \%$ of the respondents was strongly agreed that, effective leadership and good corporate governance has been a solution tools for global financial crises, 40 or $40 \%$ agreed, 2 or $2 \%$ undecided no respondents was strongly disagreed, while 4 or $4 \%$ disagreed.

Table 14: The Nigerian small scale entrepreneur needs good leadership and corporate governance for their growth.

\begin{tabular}{|l|l|l|}
\hline Respondents & No of respondent & $\%$ of Percentage \\
\hline Strongly Agreed & 44 & 44 \\
\hline Agreed & 48 & 48 \\
\hline Undecided & 6 & 6 \\
\hline Strongly Disagreed & 10 & 2 \\
\hline Disagreed & 10 & 10 \\
\hline Total & 100 & 100 \\
\hline
\end{tabular}

Source: Author's computation 2012

In respect of table 14above, 34 or $34 \%$ respondents strongly agreed 48 or $48 \%$ agreed, 6 or $6 \%$ undecided, 2 or $2 \%$ strongly disagreed none disagreed. This shows that, for the Nigeria small scale entrepreneurs to grow steadily there is need for good leadership and corporate governance to be put in place.

Table 15: Good leadership and corporate governance brings about proper management of small scale entrepreneurs' resources and enhancement of economic growth.

\begin{tabular}{|l|l|l|}
\hline Respondents & No of respondent & \% of Percentage \\
\hline Strongly Agreed & 60 & 60 \\
\hline Agreed & 38 & 38 \\
\hline Undecided & 2 & 2 \\
\hline Strongly Disagreed & 0 & 0 \\
\hline Disagreed & 0 & 0 \\
\hline Total & 100 & 100 \\
\hline
\end{tabular}

Source: Author's computation 2012

The analysis of table 15 above reveals that, a total number 60 or $60 \%$ strongly agreed that corporate governance and good leadership brings about proper management of small scale entrepreneurs' resources and enhancement of economic growth. Entrepreneurs 38 or $38 \%$ agreed, 2 or $2 \%$ undecided, while none was strongly disagreed or disagreed.

Table 16: The success of small and medium scale entrepreneurs largely depends on the efficient allocation of her scare resources by its management.

\begin{tabular}{|l|l|l|}
\hline Respondent & No of respondents & \% of respondents \\
\hline Strongly Agreed & 58 & 58 \\
\hline Agreed & 40 & 40 \\
\hline Undecided & 0 & 0 \\
\hline Strongly Disagreed & 1 & 1 \\
\hline Disagreed & 1 & 1 \\
\hline Total & 100 & 100 \\
\hline
\end{tabular}

Source: Author's computation 2012 
Table 16 above revealed that, a total of 58 or $58 \%$ strongly agreed that the success of small and medium scale entrepreneurs largely depend on the efficient allocation of their scare resources by its management, majority with a total number of 40 or $40 \%$ agreed, none undecided, 1 or $1 \%$ strongly disagreed, while 11 or $11 \%$ disagreed.

Table 17: The death of many small and medium scale entrepreneurs can be traced to the poor and ineffective leadership.

\begin{tabular}{|l|l|l|}
\hline Respondent & No of respondents & \% of respondents \\
\hline Strongly Agreed & 38 & 38 \\
\hline Agreed & 57 & 57 \\
\hline Undecided & 2 & 2 \\
\hline Strongly Disagreed & 1 & 1 \\
\hline Disagreed & 2 & 2 \\
\hline Total & 100 & 100 \\
\hline
\end{tabular}

Source: Author's computation 2012

Table 17 above indicates, 38 or $38 \%$ of the respondents strongly agreed, 57 or $57 \%$ agreed, 2 or $2 \%$ undecided, 1 or $1 \%$ strongly disagreed, while 2 or $2 \%$ disagreed. The tabular analysis shows that poor and ineffective leadership have lead to the death of many small and medium scale entrepreneurs based on the responses of the majority.

Table 18: Unethical behaviour of the leaders hinders the success of an organization.

\begin{tabular}{|l|l|l|}
\hline Respondent & No of respondents & \% of respondents \\
\hline Strongly Agreed & 50 & 50 \\
\hline Agreed & 35 & 35 \\
\hline Undecided & 5 & 5 \\
\hline Strongly Disagreed & 2 & 2 \\
\hline Disagreed & 8 & 8 \\
\hline Total & 100 & 100 \\
\hline
\end{tabular}

Source: Author's computation 2012

From table 18 above, the opinion of the respondents are as follows: 50 or $50 \%$ strongly agreed with the above question, majority with a total of 35 or $35 \%$ agreed, 5 or $5 \%$, undecided, 2 or $2 \%$ strongly disagreed, while 8 or $8 \%$ disagreed. In a nutshell, the above analysis reveals that, unethical behaviour remains one of the factors affecting the success of organizations negatively.

Table 19: Ineffectively leadership and poor corporate governance affects the development of small and medium scale entrepreneurs negatively.

\begin{tabular}{|l|l|l|}
\hline Respondent & No of respondents & \% of respondents \\
\hline Strongly Agreed & 45 & 45 \\
\hline Agreed & 46 & 46 \\
\hline Undecided & 2 & 2 \\
\hline Strongly Disagreed & 3 & 3 \\
\hline Disagreed & 4 & 4 \\
\hline Total & 100 & 100 \\
\hline
\end{tabular}

Source: Author's computation 2012

As evident by table 19 above, about 45 or $45 \%$ of the total population strong agreed, 46 or $46 \%$ agreed, 2 or $2 \%$ undecided, 3 or $3 \%$ strongly disagreed, while 4 or $4 \%$ disagreed. This shows that ineffective leadership and poor corporate governance effects the development of small and medium scale entrepreneurs negatively.

Table 20: Corporate governance aids the achievement of an organization's budget through adequate implement and monitoring.

\begin{tabular}{|l|l|l|}
\hline Respondents & No of respondent & \% of Percentage \\
\hline Strongly Agreed & 41 & 41 \\
\hline Agreed & 46 & 46 \\
\hline Undecided & 6 & 6 \\
\hline Strongly Disagreed & 2 & 2 \\
\hline Disagreed & 5 & 5 \\
\hline Total & 100 & 100 \\
\hline
\end{tabular}

Source: Author's computation 2012 
The available figures in table 20 above reveals that, 41 or $41 \%$ of the respondents strongly agreed 46 or $46 \%$ agreed, 6 or $6 \%$ undecided, 2 or $2 \%$ strongly disagreed, while 5 or $5 \%$ disagreed. As the largest population of the respondents were in support of the above question, it means that, corporate governance has been of tremendous assistance in the achievement of the organizations goals.

\subsection{PRESENTATION AND ANALYSIS OF DATA ACCORDING TO TESTS OF HYPOTHESES}

For an acceptable decision to be taken either to accept or reject the hypothesis to be tested, the hypotheses are be tested using the formula known as spearman's coefficient of rank correlation.

The formula is stated thus:

$\begin{array}{lll}\mathrm{r} & = & 1-6 \sum \mathrm{d}^{2} \\ \mathrm{n}\left(\mathrm{n}_{2}-1\right) & \\ \text { where: } & \\ \mathrm{r} & = & \text { coefficient of the correlation } \\ \mathrm{d} & = & \text { the difference between the rank of each pairs } \\ \mathrm{n} & = & \text { the number of paired observations. }\end{array}$

In order to know the strength of the relationships between the pairs (rank 1 and 2), the spearman's rank correlation shall be converted to $\mathrm{t}$ - statistics using the formula below:

$\mathrm{t}=\mathrm{r}$

where:

$\mathrm{n}=$ number of elemeht (Pairßbservation)

$\mathrm{t}=$ student's $\mathrm{t}-$ distribution

However, the null and alternative hypotheses are:

$\mathrm{H}_{0}$ : The rank correlation in the population is zero.

$\mathrm{H}_{\mathrm{i}}$ : There is a positive association among the ranks

\section{Decision Rule:}

The decision rule is to reject $\mathrm{H} 0$ if the computed value of $t$ is greater than the tabulated value of $t$ at $0.05(5 \%)$ level of significance.

\section{HYPOTHESIS ONE}

$\mathrm{H}_{0}$ : Organizational success or otherwise does not largely depend on the type or quality of leadership style used by the leaders.

$\mathrm{H}_{\mathrm{i}}$ : Organizational success or otherwise largely depends on the type or quality of leadership style used by the leaders.

Questions 4 (table 9) and 1 (table 6) in section B are used to test hypothesis one. Therefore, let X represents question 4 and let $\mathrm{Y}$ represents question 6

\begin{tabular}{|l|l|l|l|l|l|l|}
\hline Respondents & $\mathbf{X}$ & $\mathbf{Y}$ & $\mathbf{R}_{\mathbf{X}}$ & $\mathbf{R}_{\mathbf{Y}}$ & $\mathbf{R}_{\mathbf{X}}-\mathbf{R}_{\mathbf{Y}}$ & $\left(\mathbf{R}_{\mathbf{X}}-\mathbf{R}_{\mathbf{Y}}\right)^{2}$ \\
\hline Strongly Agreed & 39 & 50 & 4 & 5 & -1 & 1 \\
\hline Agreed & 53 & 43 & 5 & 4 & 1 & 1 \\
\hline Undecided & 2 & 1 & 1.5 & 1 & 0.5 & 0.25 \\
\hline Strongly Disagreed & 2 & 2 & 1.5 & 2 & -0.5 & 0.25 \\
\hline Disagreed & 4 & 4 & 3 & 3 & 0 & 0 \\
\hline Total & 100 & & & & & 2.5 \\
\hline
\end{tabular}

Computed value of $\mathrm{t}=3.1303$

Degree of freedom (d.f) $=\mathrm{n}-2$ but $\mathrm{n}=5$

d.f $=5-2=3$

Since the value could either be positive or negative, the test is one-tailed test. Therefore one tailed value of tdistribution table was used.

At d.f 3 and $0.05(5 \%)$ level of significance, tabulated value of $t=2.353$.

\section{Decision Rule:}

Since the computed value of $t$ (3.1303) is greater than the tabular value of $t$ (2.353), null hypothesis shall be rejected while alternative hypothesis shall be accepted. 


\section{HYPOTHESIS TWO}

Ho: There exist no significant relationship between leadership, corporate governance and entrepreneurship development.

Hi There exist a significant relationship between leadership, corporate governance and entrepreneurship development.

Questions 2 (table 7) and 5 (table 10) are used to test the hypothesis in order to arrive at a rightful conclusion. Therefore, let $\mathrm{X}$ represent question 2 and let $\mathrm{Y}$ represents question 5.

$\mathrm{d}^{2}$

\begin{tabular}{|l|l|l|l|l|l|l|}
\hline Respondents & $\mathbf{X}$ & $\mathbf{Y}$ & $\mathbf{R}_{\mathbf{X}}$ & $\mathbf{R}_{\mathbf{Y}}$ & $\mathbf{R}_{\mathbf{X}}-\mathbf{R}_{\mathbf{Y}}$ & $\left(\mathbf{R}_{\mathbf{X}}-\mathbf{R}_{\mathbf{Y}}\right)^{2}$ \\
\hline Strongly Agreed & 38 & 40 & 4 & 4 & 0 & 0 \\
\hline Agreed & 49 & 43 & 5 & 5 & 0 & 0 \\
\hline Undecided & 4 & 3 & 1.5 & 1 & 0.5 & 0.25 \\
\hline Strongly Disagreed & 5 & 5 & 3 & 2 & 1 & 1 \\
\hline Disagreed & 4 & 9 & 1.5 & 3 & -1.5 & 2.25 \\
\hline Total & 100 & 16 & & & & 3.5 \\
\hline
\end{tabular}

Computed value of $t=2.529$

Degree of freedom (d.f) $n-2$ but $n-5$ $5-2=3$

At d.f 3 and $0.05(5 \%)$ level of significance, tabulated value of $t=2.353$

\section{Decision Rule:}

Since the computed value of $t(2.529)$ is greater than the tabulated value of $t$ (2.353), $H_{0}$ (null) hypothesis shall be rejected while alternative hypothesis $\left(\mathrm{H}_{\mathrm{i}}\right)$ shall be accepted.

This shows that corporate governance policy has really helped Nigerian banks to grow financially since the bank consolidation. Also, corporate government as a policy, strategy, instrument or system helps every organization to achieve her goals.

\section{HYPOTHESIS THREE}

$\mathrm{H}_{0}$ : Ineffective leadership and poor corporate governance does not affect the development of small and medium scale entrepreneurs negatively.

$\mathrm{H}_{\mathrm{i}}$ : Ineffective leadership and poor corporate governance affects the development of small and medium scale entrepreneurs negatively.

To test this hypothesis, question 14 (table 19) and question 12 (table 17) are used to test the hypothesis. Therefore, let X represent question 14 and Y represent question 12

\begin{tabular}{|l|l|l|l|l|l|l|}
\hline Respondent & $\mathbf{X}$ & $\mathbf{Y}$ & $\mathbf{R}_{\mathbf{X}}$ & $\mathbf{R}_{\mathbf{Y}}$ & $\mathbf{R}_{\mathbf{X}}-\mathbf{R}_{\mathbf{Y}}$ & $\left(\mathbf{R}_{\mathbf{X}}-\mathbf{R}_{\mathbf{Y}}\right)^{2}$ \\
\hline Strongly Agreed & 45 & 38 & 4 & 4 & 0 & 0 \\
\hline Agreed & 46 & 52 & 5 & 5 & 0 & 0 \\
\hline Undecided & 2 & 3 & 1 & 2.5 & -1.5 & 2.25 \\
\hline Strongly Disagreed & 3 & 2 & 2 & 1 & 1 & 1 \\
\hline Disagreed & 4 & 3 & 3 & 2.5 & 0.5 & 0.25 \\
\hline Total & 100 & 100 & & & & 3.5 \\
\hline
\end{tabular}

Computed value of $t=2.529$

Degree of freedom (d.f) $n-2$ but $n-5$

$$
5-2=3
$$

At d.f 3 and $0.05(5 \%)$ level of significance, tabulated value of $t=2.353$.

\section{Decision Rule:}

Since the computed value of $t(2.529)$ is greater than the tabular, value of $t(2.353)$, null hypothesis $\left(\mathrm{H}_{0}\right)$ shall be rejected while alternative hypothesis $\left(\mathrm{H}_{\mathrm{i}}\right)$ shall be accepted. This reveals that ineffective leadership and poor corporate governance has been an obstacle to the development of small and medium scale entrepreneurs. Likewise, the death of many small and medium scale entrepreneur can be traced to the poor and ineffective leadership.

Having tested the formulated hypothesis, it was proved from every angle that good leadership and corporate governance in every organization, especially in the banking industry and entrepreneurship development in Nigeria and the world at large remains one and only major alternative way to restore 
accountability, honesty fairness, etc which will in turn bring about increased production economic growth and development.

\subsection{CONCLUSIONS \\ V. Summary, Conclusions And Recommendations}

Impacts of leadership and corporate governance on entrepreneurship development using Zenith Bank and Bank of industry as a survey have been reviewed in this research work.

However, different theories or approaches to leadership, importance of leadership, variables affecting leadership effectiveness, meaning of leadership and corporate governance, theories of corporate governance, effects of corporate governance on growth and development, characteristics and principles of corporate governance, legal and regulatory framework for corporate governance in Nigeria, etc were reviewed in order to know more about the importance of effective leadership and good corporate governance so as to enjoy more of the benefits accrued to these terms.

The gathered information in this research work through questionnaire were analyzed and interpreted using simple percentage table for tabular analysis and Spearman's Rank Correlation Coefficient for the testing of the formulated hypotheses so as to know more about the topic understudy. It was proved in the research carried out that, effective leadership and good corporate governance determines the success of an organization. In the analysis, corporate governance policy has really helped Nigerian entrepreneur to grow financially. Also, effective leadership and good corporate governance was seen as a solution tools for global financial crises.

Therefore, it is hereby concluded that, effective leadership and good corporate governance remains a solution tool for global financial crises, organizational problems and the right policy that enhances increased productivity that brings about economic growth and development globally.

\subsection{RECOMMENDATIONS}

In the course of carrying out this research work, many factors were found responsible for ineffective leadership and poor corporate governance in the small and medium scale entrepreneurs, and global financial crises. For this reason, the following recommendations were made to help the Nigerian banks and small and medium scale entrepreneurs to grow and wax stronger.

There is need for more awareness on the importance of good leadership and corporate governance to embrace corporate governance being a system that encourages efficient use of available scarce resources in order to achieve organizational objectives in the small and medium scale industries (SMI) and other sectors of the economy; The top management staff of every organization should do away with fraudulent acts and unethical behaviours; There should be more severe punishment for the leaders or top manager that involved in any fraudulent acts; As it was proved that, ineffective leadership and poor corporate governance hinders the development of small and medium scale entrepreneurs, government should encourage and educate them by organizing seminars, workshops, public lectures, etc about the dangers of ineffectiveness and mismanagement. It was found that corporate governance aids the achievement of an organization's budget through adequate implementation and monitoring, every organization is hereby advice not to handle corporate governance system with levity but with all seriousness to achieve greater result.

\subsection{SUGGESTIONS FOR FURTHER STUDIES}

The researcher hereby suggests that, further studies on the topic - impact of leadership and corporate governance on the banking industry and entrepreneur development, should be carried out in other industries, sectors all over the federation for comparative analysis since this study is restricted to Zenith Bank and Bank of industry both in Lagos State.

However, the findings and recommendations of such studies will be of immense benefits to students, other researchers or scholars, industrialist, entrepreneurs, bankers, political sector, and the entire nation if so strictly adhered to or implemented.

\section{References}

[1] Aghion, P. and Bolton P. (1992) An incomplete contract approach to financial contracting, review of Economic studies, Vol. 59 Pp 473-94.

[2] Akanni K.A (2010) Practice of Entrepreneurship: Principles and Strategies, Lagos: OEMAJ Internal Communication (Nig) Ltd

[3] Akinsulire, O. (2005) Financial Management. Lagos: El-Toda Venture Ltd.

[4] Amit, R. Gosten, L. and Muller E. (1993) Challenges to theory in entrepreneurship research, Journal of Management Studies, Vol. 30, No 5, Pp 815-834.

[5] Anuku, C.E.O \& Achvenu, G.A (2010) Re-engineering corporate governance enterprise sustainable. Institute of Strategic Management, Nigeria (ISMN).

[6] Asika N. (1991) Research Methodology in the Behavioural Sciences, Lagos: Longman Nigeria Plc.

[7] Asika, A (1991) Research Methodology in the behavioural sciences, Lagos: Longman Nigeria Plc.

[8] Avery, G. (2004) Understanding Leadership, London: Sage Publications.

[9] Barnard, C. (1966) The functions of the Executive, Cambridge: Harrand University Press. 
[10] Basel Committee on Banking. Supervision (2006) Enhancing Corporate Governance for Banking Organization, Switzerland and Bank for International Settlements Press and Communications.

[11] Bass, B.M (1994) Leadership and Performance beyond Expectations, in Mullins L.J (eds) Management behaviour.

[12] Bateman, T.S and Snell, S.A (2007) Management leading and Collaborating, London: Mc Graw-Hill/Irwins Company.

[13] Becht, M. Bolton, P. Roell, A. (2004) Corporate Governance and Control ECGI - Finance Working Paper No. 2.

[14] Berle, A and Means G (1932) The Modern Corporation and Private Property, New York: Macmillan.

[15] Blair M.M (1996) Wealth Creation and Wealth Sharing: a Colloquium on Corporate Governance and Human Capital, Washington.

[16] Brickley, J.A William, S.K. Jerold, L. Z. (1996) Managerial Economics \& Organizational Architecture.

[17] Brown and Company.

[18] Burns J .M (1978) Leadership, Harper \& Row in Mullins L.J (eds) Management Behaviour, England; Person Education Ltd.

[19] Calescent S. Djankov, S. \&, Lang. L. H.P (2000) The separation of Ownership end control in East Asian Corporation, Journal of Financial Economics.

[20] Central Bank of Nigeria (2002) Banking Annual Supervision Report, Abuja, CBN.

[21] CII (1997) Desirable Corporate Governance Conference of India Industry.

[22] Clarke, T and Clegg, S. (2000) Changing Paradigms: The transformation of Management Knowledge for $21^{\text {st }}$ Century, London: Harper Collins Business.

[23] Clarke, T. \& Dela R. Marie (eds) (2006) European Corporate Governance Globalization, London, and Thousand Oaks.

[24] Clarke, T. (2004) Critical Perspectives on Business and Management: 5 Volume Series on Corporate Governance - Genesis, AngloAmerican, European, Asian and Contemporary Corporate Governance London, and New York:

[25] Clarke, T. (ed) (2004) Theories of Corporate Governance: The Philosophical Foundations of Corporate Governance - Genesis, Anglo-American, European, Asian and Contemporary Corporate Governance, London and New York: Rouledge.

[26] Clarkson, M.B. (1995) A stakeholder Framework for analysing and Evaluating, Corporate Social Performance. Academy of Management Review, pg 20.

[27] Colley, J. Doyle J, Logan G, Stettinius, W. (2004) What is Corporate Governance? London: McGraw-Hill.

[28] Colley, J., Doyle, J., Logan, G. and Stettinium, W. (2004) What is Cooperate Governance: McGraw Hill, Dec. ISBN 0-07-1444483 .

[29] Collier, J. and Roberts, J. (2001) An ethic for Corporate Governance. Business Ethics Quarterly, Vol 8, Pp 679-91.

[30] Corporate Governance-Wikipedia Free Encyclopedia (2007) Internet www.wikipedia.org.

[31] Dess G.G and Lumpkin G.T (2002) Corporate Governance update for use with strategic Management creating competitive advantages, Boston: MC Graw Hill/Irwin.

[32] Dess, G.G. and Lumpkin (2002) Corporate Governance: Overview and Research Agenda, British Accounting Review, 32, pp 341 354.

[33] Dollinger, M.J. (2001) Entrepreneurship: Strategies and Resources, Upper Saddle River: Prentice Hall.

[34] Donaldson. T, and Preston, L. (1995) The stakeholder Theory of Corporation; Concepts, Evidences Implications: Academic of Management Review, Pp 20,65.

[35] Enabunene, S. (2005) Governance and Poverty Alleviation in Nigeria: Problems and Prospect National Conference, Faculty of Social Science, Ambrose Alli University Ekpoma July 4t - 6th.

[36] Federal Republic of Nigeria (1991) Company and Allied Matters Decree with Amendments.

[37] Fiedler, F.E (167) A Theory of Leadership Effectiveness, London: McGraw-Hill.

[38] Fitzroy, P. and Herbert J.M (2006) Strategic Management: Creating value in a Turbulent World, New Delhi: John Willey \& sons Inc.

[39] Freedman, R.E. and Evan, W.M (1990) Corporate governance: A stakeholder interpretation, Journal of Behavioural Economics Vol. 19, No 14, 339-359.

[40] Freeman R.E (1984) Strategies Management: A stakeholder Approach, Englewood Cliffs NJ: Prentice Hall.

[41] Freeman, R.E and Reed, W.W (1990) Corporate Governance: A stakeholder International Journal of Behavioural Economics, Pp 19.

[42] Gannon, M.J. (1977) Management: An Organization Perspective, Toronto: Little

[43] Ghartey, A. (2002) Corporate Governance: How is the Accounting profession Responding to the International Demands for Greater Transparency for good Governance and Poverty Reduction. The Nigerian Accountant, July-Sept, vol. 35 (3): 29.

[44] Gill, R (2006) Theory and Practice of Leadership -London: sage publications.

[45] Gulbury, A. (1996) Corporate Governance: Brussels: Instithet Voor Besturders.

[46] Harts, O. (1995) Firms, Contracts and Financial Structure, Oxford: Claredon Press.

[47] Hersey and Blanchard, K.H (1993) Management of Organizational behaviour: Prentice Human Resources, Sixth Edition,

[48] Hill, J. and McGowan, P. (1999) A qualitative approach to developing small firm marketing planning competencies, qualitative market research: An international Journal Vol. 2, No. 3 online

[49] Horsby A.S. (2007) Oxford Advanced Learner's Dictionary: Internal Student's Edition, 7th Ed, UK University Press.

[50] House, R.J (1971) Theory of Leadership Effectiveness, Administrative Quarterly, Vol. 16, Sept, Pp 321-38.

[51] House, R.J. and Dessler, G (174) The Path-Goal Theory of Leadership in Hunt. J. G and Larson, L.L (eds) Contingency Approaches to Leadership; Southern Illinois University.

[52] IFC (2007) International Finance Corporation Annual Report. Organization for Economic Cooperation Development.

[53] Iwuama, B.C, Ogbebor, G.G, Ohen, R \& Onwuegbe, O.C (1992) Research Methods in Education, Benin City: World of Books Publishers

[54] Jensen, M.C and Meckling (1976) Theory of the firm: Managerial behavior, agency costs and ownership structure, Journal of Financial Economics, ol. 3, No 5.

[55] Jensen, MC. and Meckling (1976) Theory of the firm: Management Behaviour, Agency Costs and Ownership structure, Journal of Financial Economics Vol 3 No4.

[56] Kamzi, A. (2003) Business policy and strategic Management, 6th Edition, New Delhi: total MacGraw Hill Publishing Company Ltd.

[57] Kazmi, A. (2003) Business Policy and Strategic Management 6th Ed, New Delhi: Total McGraw Hill Publishing Company Ltd.

[58] Keasey, K. Thompson, S. and Wright, M. (2005) Corporate Governance: Accountability, Enterprise and International Comparisons, England: John Willey 8s Sons Ltd.

[59] Kotter, J.P (1990) What Leaders Really Do, Harvard Business Review, May-June P. 103.

[60] Kreitner, R, Kinicki, A and Buclens, M. (1999) Organizational Behaviour, Houghton: Mc GrawHill, 1 st European Edition.

[61] Lawal, A.A (1993) Management in focus, Lagos: Abdul Industrial Enterprises.

[62] Lawal, A.A. (1993) Management in Focus, Lagos: Abdul Industrial Enterprises. 
[63] Letza, S. Sun, X. and Kirkbride, J (2004) Shareholding versus stakeholding: a critical review of Corporate Governance, Corporate Governance: An International Review, Vol 12 No 3:242-622.

[64] Machold S. (2004) Corporate Governance and Feminist ethics: A conceptual Model working paper senses, University of wolver Hampton. UK, in Ogundele O. J.K (eds) Introduction to Entrepreneurship Development, Corporate Governance and Small Business Management.

[65] Madueke, K. (2007) Cadbury and Future Corporation in Nigeria. National Mirror, Monday, Feb 12, Vol 3, No. 51 P 43.

[66] Maitland I. (2001) Distributive Justice in Firms: Do the rule of Corporate Governance matter? Business Ethic Quarterly, vol. 11, No 1, Pp 129-43.

[67] Marshall, T (1991) Understanding Leadership, Tonbridge: Sovereign World.

[68] Mullins, L.J (2005) Management and Organizational Behaviour, England: Person Education Ltd.

[69] Mullins, L.J. (2005) Management and Organizational Behaviour: England;

[70] OECD (1999) OECD Principles of Corporate Governance, Paris; OECD.

[71] OECD (2004) Survey of Corporate Governance Development in OECD countries, OECD Paris.

[72] Ogundele O.J.K (2007) Introduction to Entrepreneurship Development, Corporate Governance and Small Business Management, Lagos: Molofin Nominees.

[73] Ogundele, O.J.K (2007) Introduction to Entrepreneurship Development, Corporate Governance and Small Business Management, Lagos: Molofin Nominees.

[74] Ogundele, O.J.K. (2000) Ethnical Education in Manpower Development in Nigeria, Knowledge Review, Vol. 2, No 1, Nov.

[75] Ogundele, OJ.K, Alaka, N.S. an d Balogun, M.T (2005) Governance and Poverty, Poverty in Nigeria, National Conference, Faculty of Social Sciences, Ambrose Alli University, Ekpoma.

[76] Olayinka, W.K (2010) Practice and Standard of Corporate Governance in the Nigerian Banking Industry, International Journal of economics and Finance, Vol 2, No 4, Bov.

[77] Omozejie, P.I. (2005) Governance and Poverty Alleviation: The Nigerian Experience, Nation Conference; Faculty of Social Sciences, Ambrose Alli University, Ekpoma.

[78] Ostroff, F. (2006) Change Management in government, Harvard Business Review May.

[79] Osuagwu, L. (2001) Small Business and Entrepreneurship Management 2nd Ed. Lagos: Grey Resource Ltd.

[80] Osuagwu, L. (2006) Business and Research Methodology, Principles and Practice, Lagos: Grey Resource Ltd.

[81] Osuala, E.C (2005) Introduction to Research Methodology, Principles and Practice, Lagos: Grey Resource Ltd.

[82] Osuala, E.C. (2005) Introduction to Research Methodology, 3rd Ed., Onitcha: Africana-First Publisher Ltd.

[83] Owoh, G.U (2006) Corporate Governance in a Private Sector-Led Economy: Balancing the Issue. The Nigerian Banker July-Sept Pp. 7-17.

[84] Oyejide, T.A and Soyibo A. (2001) The Practice and Standard of Corporate Governance in Nigeria, DPC Research Report, 26,33.

[85] Oyejide, T.A. 8s Soyibo, A. (2001) The Practice of and standard of corporate Governance in Nigeria DPC research Report, $26,33$.

[86] Parker (2002) Governing the Corporation in Bloomsbury References Book, London: Bloomsbury Publishing Plc.

[87] Person Education Ltd.

[88] Post, J. Preston, L and Sachs, S. (2002) Managing the Extended Enterprise: The New Stakeholder View, California Management Review 45, Vol 1.

[89] Price, R.W. (2001) Entrepreneurship (Ed), New York: McGraw Hill.

[90] Richardo, E. C. (2000) Report on Corporate Governance Issue in Chile Carey CIA Ltd: Sao Parlo, April.

[91] Rossouw G.J. (2002) Business ethic and Corporate Governance in the 2nd King Report: for sight or futile? Koer. Vol 67.

[92] Schumpeter, J.A. (1934) Theory of Economics Development, Cambridge Mass: Harvard University, Sited in G. Meiver (1976) Leading Issues in Economic Development (3rd Ed) New York: Oxford University Press.

[93] Shleifer A. and Vishiny R.W (1977) A survey of Corporate Governance, Journal of Finance, 52, No 2, June.

[94] Soyibo, A Olayiwola, W.K and Alayande, B (2002) A Review of Privatization Programme in Nigeria, DPC, Research Reports 33,

[95] Soyibo, A., Olayiwola, K. \& Alayande, B. (2002) A review of Privatization Programme in Nigeria DPC Research Reports, 33.

[96] Sullivan, J.D (2000) Corporate Governance; Transparency between Governance and Business. Paper presented to the Mediterranean Development forum 3, World Bank Meeting, Cairo, Egypt March 7

[97] Tannenbaum, R and Schnidt, W.H (1973) How to choose a Leadership Patten, Harvard Business Review, May-June.

[98] Thai Institute of Directors (2002) Strengthening Corporate Governance practices in Thai Institute of Directors and McKinsey \& Company, Thailand, Thailand: Mickinsey \& Company.

[99] Uche, C. (2004) Corporate Governance in the Nigerian Financial Industry. The Nigeria Banker, July-Dec. Pp 15-20.

[100] Vroom, V.H and Jago, A.G (1988) The New Leadership: Managing Participation in organizations, in Mullions, L.J (2005) Management and organizational behaviour.

[101] Vroom, V.H and Yetton, P.W (173) Leadership and Decision-making in Mullins, L.J Management, England, Person Education Ltd.

[102] Wearing, R. (2005) Cases in Corporate Governance; London: Sage Publications.

[103] Whitehead, M. (2002) Everyone's Leader Now, supply Management, 25 April.

[104] Wilson, I. (2006) Regulatory and International challenges of Corporate Governance in Nigeria Post Banking Consolidation: Nigerian Economic Summit Group (NESG) Economic Indicators, April June Vol 12 No 2.

[105] Zingales L. (1998) Corporate Governance; The New Palgrave Dictionary.

\section{QUESTIONNAIRE \\ LAGOS STATE UNIVERSITY, FACULTY OF SOCIAL SCIENCES, DEBARMENT OF ECONOMICS \\ Dear respondent,}

I am a lecturer of the above named institution carrying out a research on the topic: The Impact of Leadership and Corporate Governance on Entrepreneurship Development in Nigeria. The questionnaire is designed and served to facilitate the collection of relevant data which will be used to carry out a successful research work. I hereby promise to use any information provided solely for academic purpose.

Thanks for your cooperation.

Yours faithfully,

\section{Atoyebi Kehinde 0.}




\section{QUESTIONNAIRE \\ SECTION A \\ BIO-DATA}

Instruction: Please tick $(\sqrt{ })$ the appropriate answer from the options provided.

Sex Distribution

Male

Female ( )

2. Age Distribution

$21-30 \mathrm{yrs}$

( )

31-40yrs ( )

41-50yrs ( )

51-60yrs ( )

60 years and above

Marital Status

Single

Married

Divorced

Widow (er)

Educational Qualification

ND/NCE

$\mathrm{HND} / \mathrm{B} . \mathrm{Sc}$

$\mathrm{MBA} / \mathrm{M} . \mathrm{Sc}$

Others

5. Work Experience

(a) $\quad 0-5 y r s$

(b) 6-10yrs

(c) 11-15yrs

\begin{tabular}{|l|l|l|l|l|l|l|}
\hline & \multicolumn{1}{|l|}{ SA } & A & UD & SD & D \\
\hline 1. & $\begin{array}{l}\text { Leadership and Corporate governance are essential ingredient for } \\
\text { organizational development. }\end{array}$ & & & & \\
\hline 2. & $\begin{array}{l}\text { There exist a significance relationship between leadership, } \\
\text { corporate governance and entrepreneurship development. }\end{array}$ & & & & \\
\hline 3. & $\begin{array}{l}\text { An organization cannot function effectively without effective } \\
\text { leadership }\end{array}$ & & & & \\
\hline 4. & $\begin{array}{l}\text { Organizational success or otherwise depends largely on the type } \\
\text { or quality of leadership style used by the leaders. }\end{array}$ & & & & \\
\hline 5. & $\begin{array}{l}\text { Effective leadership and good corporate governance create the } \\
\text { right climate for effective production and job satisfaction. }\end{array}$ & & & & \\
\hline 6. & $\begin{array}{l}\text { Corporate governance as a policy, strategy, instrument or system } \\
\text { helps every organization to achieve her goals. }\end{array}$ & & & & \\
\hline 7. & $\begin{array}{l}\text { Global financial crisis is one of the major reasons for the general } \\
\text { acceptance of corporate governance policy. }\end{array}$ & & & & \\
\hline 8. & $\begin{array}{l}\text { Effective leadership and good corporate governance has been a } \\
\text { solution tools for global financial crisis. }\end{array}$ & $\begin{array}{l}\text { The Nigerian small scale entrepreneurs need good leadership and } \\
\text { corporate governance for its growth. }\end{array}$ & & & & \\
\hline 9. & $\begin{array}{l}\text { Good leadership and corporate governance brings about proper } \\
\text { management of small scale entrepreneurs' resources and enhance } \\
\text { economic growth. }\end{array}$ & & & & \\
\hline 11. & $\begin{array}{l}\text { The productivity of small and medium scale entrepreneurs largely } \\
\text { on the efficient allocation of her scarce resources by its } \\
\text { management. }\end{array}$ & & & & \\
\hline 12. & $\begin{array}{l}\text { The death of several small and medium scale entrepreneurs can } \\
\text { be traced to the poor and inefficient management. }\end{array}$ & & & & \\
\hline 13. & $\begin{array}{l}\text { Unethical behaviour of the leaders hinders the success of an } \\
\text { organization. }\end{array}$ & & & & \\
\hline
\end{tabular}




\begin{tabular}{|l|l|l|l|l|l|l|}
\hline 14. & $\begin{array}{l}\text { Poor leadership and corporate governance affects the } \\
\text { development of small and medium scale entrepreneurs. }\end{array}$ & & & & \\
\hline 15. & $\begin{array}{l}\text { Corporate governance aids the achievement of an organization's } \\
\text { budget through adequate implementation and monitoring. }\end{array}$ & & & & \\
\hline
\end{tabular}

(d) $16 y r s$ and above

\section{SECTION B}

RESEARCH QUESTIONS

INSTRUCTION: In the following questions kindly tick $(\sqrt{ })$ the appropriate answer that represents your opinion on the question.

The following abbreviation will help you to answer the questions below.
$(\mathrm{SA})=$ Strongly Agree
(A) $\quad=\quad$ Agreed
(D) $\quad=\quad$ Undecided
(SD) = Strongly Disagree
(D) $=$ Disagree 